\title{
Legal Consensus as to Embargo Claims; an Investigative Study
}

\author{
Chandana Jayalath
}

Qserve Qatar Ltd

\begin{abstract}
Certain political sanctions have been recently imposed against Qatar by Bahrain, Egypt, Saudi Arabia and the United Arab Emirates. Given the fact that Qatar is very busy constructing a number of projects in preparation for the FIFA World Cup in 2022, it's unsurprising that the Quantity Surveyors have had some requests for advice from contractors whose operations in Qatar have been affected by the sanctions and who are looking for a means of claiming extension of time and/or damages. Equitable principles codified in the Qatar Civil Law include the requirement for parties to a contract to conduct themselves "consistent with the dictates of good faith" and an implied duty of the employer to cooperate with its contractors and not to delay or prevent their contract performance. Furthermore, where a contractor has suffered excessive losses arising from exceptional events the contractor may be able to raise an exceptional event's argument pursuant to Article 171 of the Qatar Civil Law, and if successful, the approach is to reduce the contractor's burdensome obligation to a reasonable limit after balancing the interests of the parties. This paper is to explore the legal consensus pertaining the embargo in Qatar using civil codified law provisions, standard forms of contracts for public works and the author's firsthand experience in drafting and review of claims on embargo.
\end{abstract}

Key words: damages, disruption, embargo, force majeure, lump sum, special risks

\section{Introduction}

Construction contractors in Qatar are facing a considerable financial hardship in dealing with the open market vacillations that has been exacerbated by the embargo since June 2017. Contractors seek a fair and reasonable cost reimbursement. Hence, the objective of this research is to explore and gauge the potential of contractor's eligibility in the said circumstances.

These impacts basically include such things encountered during the progress of works which has been severely hampered by the imposition of embargo, blockage and connected hardship undergone by the contractors in the import of materials from neighbor countries. The additional costs are basically due to the costs of increase in material prices, change in suppliers, increase in cost of transport/mode of transport, change in approved sources, change in routes and cost impact due to congestion at ports and nonavailability of vessels. However, it must be noted that there are customs-related transaction costs, costs on changes in sequence of work, idling labour, plant and equipment, additional protective measures at site level, additional surcharge paid for materials transit, additional managerial costs to deal with authorities in clearance and approvals, etc for which the contractors expect from their employers a holistic outlook while reviewing claims. In doing so, they intend that their claims will be treated as a formal request to be put in the same position had there been no embargo at the time of tendering. The principle behind compensation is to bring back the losing party financially had there been no disruption (1).

These changes and additions have been mostly related to major cost significant materials such as bitumen, guardrails, road marking paints, street lights and accessories, ductile iron fittings and spares, waterproofing materials, anticarbonation paint, vitrified clay pipes, plywood and timber, collocated gantries, formwork material, friction ties and consumables, for example. Contractors contend that the procurement of these materials and components, either manufactured and/or assembled off site, have been envisaged from the neighboring countries, being products of national origin, 
compatible with the specifications. Further, they wish to exclusively note that the issue of escalation and embargo has been vis-à-vis the dominant cause for incurring additional cost in procuring major materials for permanent works. Contractors therefore intend to demonstrate the combined overall monetary effect on the cash flow and how it materially differed from what was indeed envisaged in the tender.

\section{Contractual position}

As per clause 19 of the Conditions of Contract ${ }^{\mathrm{i}}$, the Employer shall indemnify and save harmless the Contractor against and from the same and against and from all claims, damages, cost, charges etc, and shall compensate the Contractor from any loss or damage to property of the Contractor, ... with regard to Special Risksii Special risk is a collective term to encompass a wide array of expressed events (2). As per clause 19.2 - Effect of Special Risk, neither the Employer nor Contractor shall be considered in default or in contractual breach to the extent that performance of obligations is prevented by a Special Risk event which arises after the Effective Date ${ }^{\mathrm{iii}}$.

In pursuant to the Clause 19.3 Contractor's Responsibility, the Contractor shall promptly notify the Engineer and shall endeavor to continue to perform his obligations as far as reasonably practicable. The Clause 19.4 Employer's Responsibility mandates the Employer also to promptly notify the Contractor and make every possible endeavor he can to continue to perform his obligations as far as reasonably practicable. The clause 19.5 is related to payment to the contractor. If, in consequence of a Special Risk, the works shall suffer loss or damage... and if Contractor incurs additional Cost, such cost shall be determined by the Engineer in accordance the provisions of the subclause 3.5 and shall be added to the Contract price. Also revealed is that embargo is, in certain bespoken contracts, a matter of force majeure ${ }^{\text {iv }}$.

It is therefore more by way of explanation as to why the claimed amount should be paid rather than an aggressive one. The Contractor recognizes that there are different methods of determining costs and that these will not arrive at the same values. Which method of determining costs is the most appropriate is a matter of subsequent discussion if the Employer or the Engineer has a different approach (3). Indeed, the
Contractor adopts fairly an easily understood approach to calculate the additional costs. It must also be noted that the Contractor has usually an express obligation to secure its contractual right by being complaint (serving proper and timely notice within 28 days and, furnishing detail particulars of the claim, subsequent to such notice) as per clause 20.1 of the Conditions of Contract.

The Contractor trusts that the Engineer shall closely peruse, review and analyse the Claim in consultation with the Contractor in an endeavor to reach agreement pursuant to Clause 3.5; (Engineer to Attempt Agreement,) of the Conditions of Contract and that the Engineer shall determine the amount(s) due under the claimed heads fairly and reasonably. It was revealed that these claims are submitted without prejudice to any other claims that have been made or may be made or entitlements that may be pursued by the Contractor.

\section{Legal position}

While contracts have the force of law between contracting parties following the basic tenet pacta sunt servanda (which is enshrined in Article 171 of the Civil Code of Qatar), there is no argument that provisions of the Civil Code prevail over contract clauses. Under the laws of a number of civil law countries, even though a contract may not contain a price escalation clause, contractors can, when faced with an unforeseeable and exceptional loss, obtain a reasonable adjustment to the contract price. Hence, a narrative on the judicial treatment on disruptive such events and risk the way the risks are better allocated is of paramount significance. As a matter of confidence and certainty, the Contractor has put forward in point form the salient features of the relevant legal provisions and the way the special risks and open market vacillations have been treated and judicially recognized, as a part of their claims in nutshell.

The doctrine of force majeure is recognized under Law No. 22 of 2004 in the Qatari Civil Code in the State of Qatar. Articles 204 and 258 both articulate the concept of force majeure and provide relief to the non-performing party in the circumstances where another party's loss can be attributed to an external cause, or, more in-line with the traditional concept of force majeure, where the non-performance itself is due to an extraneous cause. The Qatari diplomatic 
crisis is a qualifying event for contracts that contain a similar definition and its civil procedure offers a series of legal remedies and obligations underlying the operation of contractual relationships as follows;

1. Article 171(2) of the Civil Code provides that where, as a result of exceptional and unforeseeable events, the fulfillment of the contractual obligation, though not impossible, becomes excessively onerous in such a way as to threaten the obligor with exorbitant loss, the court may, according to the circumstances and after taking into consideration the interests of both parties, reduce the excessive obligation to a reasonable level. This is a mandatory provision under Qatari law that parties cannot contractually exclude. However, under Article (171) (2) of the Civil Law, a debtor can apply to the court to have his contractual obligation reduced to a "reasonable margin" in certain "force majeure type" scenarios. A court (or arbitral tribunal) can, after weighing up the interests of the parties, reduce an "exhausting" contractual obligation to a "reasonable margin".

2. Article 188(1) of the Civil Code provides that, where the performance of one of the parties' obligations becomes impossible (i.e., more than just difficult) for an extraneous cause beyond its control, the corresponding obligation shall cease and the contract automatically rescinded. (Nevertheless the Contractor has continued fulfilling its obligations)

3. Article 188(2) of the Civil Code provides that where there is partial impossibility, a party may request the performance of the residual obligations that remain possible to perform, or request the dissolution of the contract.

4. Article 191 of the Civil Code provides a potential way to deal with frustration as it provides that a party may decline to perform its obligation if the other has failed to perform its corresponding obligation.

5. The concept of force majeure is provided for under article 204 of the Civil Code. If a party can demonstrate that a loss has arisen due to an external cause that is not of their making, the party is not liable for the damages, unless the parties have contractually agreed otherwise.

6. Article 258 of the Civil Code permits the contractual allocation of risk to the contractor for events it cannot foresee or control, with the exception of the exceptional incidents contemplated by article 171(2) of the Civil Code (which cannot be contractually excluded by the parties as per article 171(3)). Therefore, if a contract term transfers this risk, it will be generally binding and enforceable.

7. Article 259 (1) of the Civil Code provides that a party may agree to discharge the other from a liability arising from its failure or delay to perform a contractual obligation, except in cases of fraud or gross negligence.

8. With particular regard to the construction industry, Article (700) of the Civil Law provides that contractors cannot avoid or vary their contractual obligations and agreed terms as a result of price increases in the market (for example, raw materials, labour and so on) which were either unforeseeable or were outside his control. However, this provision is also subject to Article (171) (2) of the Civil Law.

9. Article 700 of the Civil Code provides that an increase in the price of raw materials, labour or other expenditure shall not give rise to an entitlement of the contractor or otherwise vary the obligations imposed by the construction contract. This is except where the price escalation came about as a result of an "exceptional incident" such as embargo for example.

\section{Notice and mitigation}

For a contractor, a precise and unambiguous notice provision may assist by making it clear what the contractor must do if it hits problems such as delay and needs to extend the completion date or claim additional money (4). For an Employer, notices are an essential means of managing finances and budget. Notices assist the Employer with making informed decisions about whether, for instance, to proceed with a variation, a course of action that may cause delay or disruption or a course of action in order to mitigate such effects (5). The operative portion of a Special Risk clause will generally contain requirements regarding notification of the occurrence of an exceptional event and the need to mitigate the effect of such event.

Claims for relief may be barred to the extent that a party fails to follow a mandated procedure set out in the contract. As a minimum, prompt notice from an affected party may well be required in 
order to preserve that party's rights to claim force majeure relief at a later date (6). It may be argued, for instance, that an Employer is not entitled to deny a Contractor its claim on grounds of lack of notice in circumstances where to do so would be a breach of the requirements of good faith as required by Article 172 of the Qatar Civil Code and/ or an abuse of rights contrary to Article 63 of the Qatar Civil Code.

The Contractor wishes to rely on Special Risks provision and intend to establish that the events in question had a sufficiently serious effect on continuing with the project- whether as regards work on site or the financial implications of continuing with the work (if relevant under the contract in question). It can therefore be concluded that the Contractor shall promptly notify the Engineer and shall endeavor to continue to perform its obligations as far as reasonably practicable. The foregoing obligation has been a reciprocal obligation and is a fact that a market order typically deals with the execution of the order where the price of the materials is linked with the speed of completing the trade. However, with the limited orders the delivery is resting within the parameters set in the consignments where the transaction cost hikes up due to market pressure from all corners.

In practice, sanctions can prove a real headache for industry and commerce alike by interfering with existing or pending contractual arrangements (7). Their violation can have serious economic and reputational repercussions, and can even lead to frustration and contractual repudiation. Under the mitigation of damages doctrine, a person who has suffered an injury or loss should take reasonable action, where possible, to avoid additional injury or loss. The failure of a plaintiff to take protective steps after suffering an injury or loss can reduce the amount of the plaintiff's recovery (8). It is a kind of doctrine that encourages avoidance of major losses. As experienced contractors, it is contractually obliged to take mitigation measures were taken to reduce the impact of embargo so as to have less impact on the progress of the project. Few of the mitigations measures taken by the Contractor us include change in sequence, substitution of materials, change in source of materials, accelerating the delivery etc.

\section{Conclusion}

The legal cases that have truly served to test the doctrine of foreseeability, commercial impracticability and hardships, have attempted to make the legal application sensible, whether contractual relations were formed in a context, if not of war, of the shortages and inflation delay in deliveries etc. Similarly, under the laws of many Arab countries, influenced by Islamic law with its emphasis on equity, adjustment of the contract price is possible where the contractor has encountered severe, unforeseeable conditions that are altogether commercially onerous or otherwise.

Equitable principles codified in the Qatar Civil Law include the requirement for parties to a contract to conduct themselves "consistent with the dictates of good faith" and an implied duty of the employer to cooperate with its contractors and not to delay or prevent their contract performance, for example where rise in material prices is massive and unforeseeable. Furthermore, where the contractor has suffered excessive losses arising from exceptional events (general price escalation in the open market as a ripple effect of the embargo, blockade, shortage etc) that could not have been foreseen, the contractor may be able to raise an exceptional event's argument pursuant to Article 171 of the Qatar Civil Law, and if successful, the approach is to reduce the contractor's burdensome obligation to a reasonable limit after balancing the interests of the parties. On balance, there does appear to be a growing judicial willingness to examine more closely the facts and the relative positions of the parties in these cases.

\section{References}

[1] Davidson, Peter (2003) Evaluating Contract Claims, Blackwell Publishing

[2] Nicholas J Carnell, (2005) Causation and Delays in Construction, $2^{\text {nd }}$ edition, Blackwell Publishing

[3] Pickavance, K (2005) Delay and Disruption in Construction Contracts, 3rd edn, Informa Legal Publishing, London.

[4] Cliffs, NJ. Murdoch, J. and Hughes, W. (2000), Construction Contracts: Law and Management, 3rd edn, Spon Press

[5] Philip Davenport (2006) Construction Claims, 2nd edition, The Federation Press

[6] Cushman RF, CM Jacobsen \& PJ Trimble (eds) (1996) Proving and pricing construction claims, Wiley, New York 
[7] Drezner Daniel W., (2000) "Bargaining, Enforcement, and Multilateral Sanctions: When Is Cooperation Counterproductive?", International Organization, 54(1), pp.73-102.

[8] Iain Murdoch, (2003) Limitations of Liability in Construction contracts, IHL

\footnotetext{
' Conditions of Contract for Building and Civil Engineering Works, Public Works Authority, State of Qatar

ii An event beyond the control of the Employer and the Contractor which makes it impossible or illegal for a party to perform, including but not limited to: $\mathrm{o}$ a) war hostilities, (whether war declared or not) invasion, act of foreign enemies, mobilization, requisition or embargo; $b$ ) Rebellion, Revolution, insurrection or military or usurped power, civil war; c) Contamination by radio-activity from nuclear fuel, or from any nuclear waste from combustion of nuclear fuel, hazardous properties of any explosive nuclear assembly. d) Riot, commotion or disorder.

iii the final date that all parties have signed the contract

iv unforeseeable circumstances that prevent someone from fulfilling a contract
}

\section{Author profile}

Chandana Jayalath D. Sc. (Eng Mgt), M. Sc. (Proj Mgt), B. Sc. (QS) Hons, PG Dip (Cons Mgt), PG Dip (Intl' Mediation), FRICS, MCIArb, F.I.Q.S.SL has been a chartered quantity surveyor for 25 years, currently working as a Senior Contracts and Claims Specialist in the Qserve Group of Companies. 